\title{
Restructuring the Business/Accounting Education Curriculum for Sustainable Development: Instilling Entrepreneurial Consciousness into Students in Tertiary Institutions
}

\author{
Dr. Fasae, Felicia Bosede Kehinde ${ }^{1 *}$, Dr. Adeosun, Omoniyi Alabi ${ }^{2}$ \\ ${ }^{I}$ Department of Office and Information Management, Bamidele Olumilua University of Education, Science and \\ Technology, Ikere-Ekiti \\ ${ }^{2}$ Department of Accounting, Bamidele Olumilua University of Education, Science and Technology, Ikere-Ekiti \\ *Corresponding Author: Dr. Fasae, Felicia Bosede Kehinde, Department of Office and Information \\ Management, Bamidele Olumilua University of Education, Science and Technology, Ikere-Ekiti, Nigeria
}

\begin{abstract}
This study examined restructuring the Business/Accounting Education curriculum for sustainable development: instilling entrepreneurial consciousness into students in tertiary institutions. The study adopted descriptive research design of a survey type. Two research questions were raised while two hypotheses were formulated to guide the study. The population consisted of 500 respondents which were all the business/accounting education students of University of Nigeria, Nsukka, Ikere-Ekiti Campus. The sample was 80 respondents randomly selected from the population. The instrument for the study was questionnaire which was properly validated by experts in Business and Accounting Education departments and was tested for reliability using Alpha Crombach method of reliability with a coefficient of 0.72 which was high enough for the study. Data collected were analysed using descriptive statistics of percentage, means and standard deviation to answer the research questions while inferential statistics of t-test was used to test the hypotheses at 0.05 level of significance. It was revealed that students of Accounting and Business Education are aware of the unemployment situation in the country, felt they are prepared but have very low level of entrepreneurship consciousness for self-sustainability. It was concluded that inculcating entrepreneurship consciousness into the Business/Accounting Education programmes by way of providing practical experiences, will increase self-sustainability of students and reduce unemployment in the country and consequently, social vices. It was recommended that the curriculum should be restructured to ensure that entrepreneurship is emphasized in core areas in business/accounting education programmes and that tertiary institution should provide entrepreneurship centres where students can have practical experiences that will quicken the consciousness in students, among others.
\end{abstract}

\section{INTRODUCTION}

Education is a vital tool for social change and personal development. An educated person is expected to think right and act right. According to Oghiagbephan (2015), citing Ayara (2007), education creates improved citizens and helps to upgrade the general standard of living in a society and that positive social change is likely to be associated with the production of qualitative citizenry. It would seem to follow naturally that if more individuals are educated, the wealth of nation would rise, since more education attracts higher wages and, aggregately, higher national income, and if there are positive externalities of education, national income should increase by even more than the sum of the individual benefits. This increasing faith in education as an agent of change in many developing countries including Nigeria has led to a heavy investment in it, and thus the delegation of manpower development to the schools. The aim of higher education in Nigeria is to produce graduates equipped with generic skills necessary for the improvement of the nation's economy. Education therefore represents a significant medium of transferring knowledge, values, morals, culture and skills to succeeding generation (Peter, 2015).

After graduation from tertiary institutions, students of business/accounting education are not expected to stay at home, expecting non-existing white collar jobs. This is because business education is the education for the acquisition and development of skills and competencies, attitudes and attributes which are necessary for efficiency of the economic system. It helps individuals to acquire saleable skills which will enable them fit into various business organizations or be self-employed in the absence of paid employment (Okoli \&Azhi, 2015), citing Aliyu (2006). 
The Nigerian nation is characterized with high rate of unemployment and this results into a lot of vices ranging from insecurity, kidnapping, and poverty, among others. Imam (2001) described unemployment and poverty as a very dangerous development that must be tackled to prevent its dangerous damage to the nation's economy. He opines that inability of graduates to secure gainful employment opportunities is due to the problem of formal educational system which did not prepare them for gainful living. It is also observed that so many qualified graduates are roaming around the country searching for jobs due to the fact that university educational system produce graduates without considering the economy, the needs of the people and the society or the curriculum content does not contain much of entrepreneurial education which entails self-reliance and self-employment.

Students of nowadays are very indifferent, even to things that concern and affect their lives and future. There is the need to engender the entrepreneurship spirit in students while in school so that they can have the mindset to engage in any trade(s) for their sustainability after school. Entrepreneurship development is the process of enhancing entrepreneurial skills and knowledge through structured training and institution building programmes. Entrepreneurship development concentrates more on growth, potential and innovation (UNDP, 2010). Peter (2015), citing Elumelu (2015), defined entrepreneurship as a means by which one no longer waits to see who will give him a job, but rather seizes the opportunity to secure his future and in the process creates job and livelihood for others. Elumelu (2015) charges graduates to start now, not to wait for the perfect time, and that the right time is now.

Studies have shown that graduates do not possess the required skills for the world of work. Iseniyi (2009) observed that the present situation of Business education curriculum is not meeting employers demand. She observed that the present curriculum of business education that is outdated, theoretically based, no correlation of subjects, as a result, no uniformity in the courses taught, and university business education graduates are not doing well in the entrepreneurial ambitions. Udu (2014) noted that in the past, Nigerian educational system did not pay much attention to the handling of entrepreneurship education as esoteric and modularize approaches were used in the handling of entrepreneurship education. As a result only few individuals and higher institutions showed interest. The few that showed interest partly misconstrued entrepreneurship and didactically taught it as most other general subjects can or should be taught, that is, listen and take notes approach.

Okoli and Azhi (2015) citing Ogakwu, (2011) observed that there is increasing level of unemployment in the country because our educational system as conceived in the past was white collar job oriented. The educational curriculum does not balance theoretical training with skill acquisition for self-reliance. Hence the need for educators and policy formulators to ensure that the general course contents and curriculum especially at all the levels of education are structured to meet our needs as a developing nation and that all levels of education in the context of current social and economic reforms should provide learners with functional knowledge and skills for productive life and for contributing to societal development. Oghiagbephan (2015) also noted that educational policies do not seem to correlate with economic needs, thus, with the much emphasis on compulsory education, increase in school enrolment at all levels and the proliferation of universities in the country, national productivity and economic development remain stiffened.

Curriculum is a group of courses or planned experience, in proper sequence of topics designed to prepare an individual for efficient service in a specific vocation. It is seen as the instrument/means of which educational institutions seek to translate the hopes of the society into a concrete reality (Okoro, 2013). He noted that Isyaku (2006) and Okike (2011) are of the opinion that an ideal curriculum can be planned and organized by experts and can be implemented and attained. Curriculum development is basically concerned with content development with other areas related to it. It is the process by which a content is identified, sequenced experiences selected and knowledge organized.

Business education is education for and about business. The aim of business education at the university level is to ensure that students are prepared for employment after graduation. The curriculum of business education has to be tilted towards job opportunities and how to possess some qualities. Okoro's (2013) study revealed that an ideal university business education curriculum should be comprehensive in scope, varied in nature, correlate with subjects, provide entry into jobs, provide opportunities for dropouts, provide acceleration for individualized at all levels, constantly reviewed to provide new ideas. An ideal business education curriculum could result to successful graduate 
Restructuring the Business/Accounting Education Curriculum for Sustainable Development: Instilling Entrepreneurial Consciousness into Students in Tertiary Institutions

employment and this will reduce high rate of graduates' unemployment. Business education graduates that have acquired skills in the business education curriculum could also run their businesses successfully without failure.

Uwadiegwu (2013) stated that restructuring in the Nigerian context can be taken to be changing or replacing a system or organization with something new and different. In the academic context, it connotes curriculum change. It means replacing the existing system or programme with something entirely new. It entails an improvement or modification of the system with the intention of changing it if necessary. There is therefore the need to restructure the business education curriculum to include entrepreneurship courses at all levels of education. According to Oghiagbephan (2015), given this concern, there is need to develop knowledge-based educational curriculum in core economic areas that require building a strong link between universities and industry for research, development and entrepreneurship. This will involve creating opportunities in collaboration at institutional level, capturing the labour market and private sector needs, and capturing needs in capacity building in quality assurance, research and leadership development in higher education.

Peter (2015) observed that the growing demand and popularity of entrepreneurship education in recent years has led to the establishment of special centres in universities for the delivering of specific curriculum instructions on entrepreneurship and other innovative subjects as new venture creation, enterprise development and capacity building. The real essence of entrepreneurship education is to ensure the improvement of educational quality by equipping the young ones with basic skills that will make them functional and productive in the society (Enu, 2004). Peter (2015) stated that universities are centres of learning which have always been places where the skills and knowledge of students are chiseled to suit the requirements and structure courses in a way that will help their students or graduates to be gainfully employed in the labour market. This acquisition of skill has much implication for the curricula, instructional procedures and on students as a whole. The curriculum contents of entrepreneurship education should enable students to attain the society's expectations and needs.

Udu (2014) applauds the current level of consciousness in entrepreneurship education as a welcome development but that it needs immediate agenda setting to be sustained and that the universities should encourage multidisciplinary entrepreneurship clubs formation - the gathering and networking of students with related felt need and world view. Incubation centers of medium standard will provide a good platform for the students and staff to test the feasibility and viability of any germane idea generated either in the clubs or through networks under the guidance of experts. There is a need for the inclusion of entrepreneurs (mentors and role models) in the teaching of entrepreneurship in tertiary institutions. Bakar, Islam and Lee (2015) asserted that many countries in the world are looking towards using entrepreneurship education as a medium to instill the entrepreneurial drive among individuals and that a country like Nigeria is looking towards entrepreneurship education as a method to ease poverty.

However, entrepreneurship itself is more than a simple creation of a business. It is a unified concept that allows entrepreneurs to develop their business in an innovative manner that consequently transforms the way business is conducted in every country (Kuratko, 2003). Entrepreneurship education has the possibility to stimulate consciousness towards self-employment as a career option; the consciousness towards self-employment inspires young people to equip themselves with the knowledge, skills and experience needed to acquire a successful business (Flemming, 1996 as cited in Ahmad, 2013). Students who take part in entrepreneurship programmes tend to have a higher possibility to start their own business (Matlay, 2008).

The basic goal of entrepreneurship education is to foster the entrepreneurial culture among students. Alain (2009) and Akudolu (2010) see entrepreneurship education as the nurturing of entrepreneurial mindsets, attitudes and skills which allow the individual to take charge of the economic situation and to identify opportunities.

Universities and polytechnics in Nigeria hold the responsibility of transferring entrepreneurial knowledge to students. The roles of the universities, polytechnics and colleges are, not only to educate students about entrepreneurship education, but also to ensure that entrepreneurship education is well established in all higher education institutions and a curriculum for the course is formed. The current development in entrepreneurship education in Nigeria is at a decreasing speed because 
entrepreneurship education is introduced at a late stage to Nigeria. Entrepneurship education is facing certain challenges such as feeble state of implementation (Akhuemonkhan, Raimi, \& Sofoluwe, 2013) and excessive stress on writing business plans in students which has caused a flaw in the method of teaching entrepreneurship education (Ifedili \& Ofoegbu, 2011). Entrepreneurship education is conveyed much well if it is conducted through talks and implementations of business projects for the students to experience activities about entrepreneurship (Akhuemonkhan, Raimi, \& Sofoluwe, 2013). Another current obstacle that Nigeria is facing is funding; inability to obtain funding has caused the implementation of entrepreneurship education curricula to be affected in a damaging manner. Also, there is also the inaccurate perception from students thinking that entrepreneurship education is enforced by the government to multiply their workload (Ifedili \& Ofoegbu, 2011; Gabadeen \& Raimi, 2012), this belief has caused students to be disheartened in venturing into entrepreneurship activities inside and outside the classroom (Ifedili \& Ofoegbu, 2011).

In view of the important role of education, tertiary institutions should strive to equip undergraduates with saleable skills that will make them self-reliant before leaving school since the while collar jobs are no longer feasible. In the observations of Aniekwu and Ozochi (2010), for individuals and for countries, education is the key to creating, adapting and spreading knowledge. Basic education increases people's capacity to learn and to interpret information but higher education increases the technical training needed to build a labour force that can keep up with a constant stream of technological advances, which compress product cycles and speed the depreciation of human capital. Outside the classroom, peoples' working and living environments are the setting for still more learning, well beyond the ages associated with formal education. Tertiary institutions definitely have a role to play in preparing the youth for the world of self-employment. This underscores the importance of the introduction of enterprise education in the curriculum of universities and other tertiary institutions.

There is the need to diversify the Business Education curriculum to integrate a functional entrepreneurial education as part of the curriculum, so as to enhance human capacity building which will reduce unemployment and poverty and ultimately eliminate incidence of cultism, prostitution, kidnapping, killings and hostage taking which are sometimes associated with unemployment which is c?ommon with the youth. Okoro (2013) averred that business education curriculum thrives on relevance and usefulness. The extent to which a curriculum assists students to enter and succeed in the business world-of-work is what matters most. Consequently, a curriculum should be dynamic.

Rahim (2014) proposed 10 ways Universities can improve entrepreneurship education as follows:

1. Focus more on case studies

2. Link curricula to real-world business challenges

3. Create opportunities for students to participate in social entrepreneurship contests

4. Partner with businesses

5. Invite business executives to deliver lectures

6. Provide consulting services to small businesses and nonprofits

7. Help students launch their own businesses

8. Emphasize technology topics in curricula

9. Foster global exchange programs with other institutions

10. Encourage student-in-residence programs

Rahim (2014) suggests further that to encourage entrepreneurship in students, whether it be social or for-profit, universities must offer more practical coursework, blending the theory in the traditional economic literature with the tangible needs of everyday business management. The education should be experiential, hands-on, and action-driven to give students a real-world experience.

\section{Statement Of The Problem}

In spite of the high rate of unemployment in the Nigerian society and the huge investment in education, it seems that tertiary institution business/accounting education students are not prepared to 
face the unemployment challenges and do not possess the entrepreneurship consciousness of self sustainability at the end of schooling. Rather, Ayara, (2007) observed that the education received further deepens social inequality and inculcate negative social changes such as cultism, rent seeking, sexual harassment, sorting, result racketeering, industrial disputes, brain drain among other social vices in the Nigerian school system and the society at large. It has also been observed that those in employment have poor inadequate skills.

Furthermore, the so much emphasized entrepreneurial skills are not possessed by business education graduates and those in school are not even conscious of this. It also seems as if the business education curriculum does not emphasize possession of entrepreneurial skills as emphasis is still on certificate which has led to the turnout of unbaked and half baked graduates who cannot meet job requirements even when they find the opportunity.

\subsection{Purpose of the Study}

The purpose of the study was:

1. to find out the extent of business/accounting education students' awareness of the unemployment situation in the country and their level of preparedness to face the challenges;

2. to find out the extent of business/accounting education students' awareness of the unemployment situation in the country and their entrepreneurship consciousness for self- sustainability.

\subsection{Research Questions}

1. What is the level of awareness of business/accounting education students of the unemployment situation in the country and their level of preparedness to face the challenges?

2. Are business/accounting education students aware of the unemployment situation in the country and do they have the entrepreneurship consciousness for self-sustainability after school?

\subsection{Research Hypotheses}

1. There is no significance difference in the responses of Business and Accounting Education students on awareness of the unemployment situation in Nigeria and their preparedness to face the challenges.

2. There is no significant difference in the responses of Business and Accounting Education students on awareness of the unemployment situation in Nigeria and their entrepreneurship consciousness for self-sustainability.

\subsection{Significance of the Study}

The study will be significant in that it could expose the level of curriculum inadequacy in preparing business education students for the unemployment situation in the country and the world of work. It could also expose business education students' level of preparedness and entrepreneurship consciousness in facing the unemployment challenges in the country and what is needed to get them ready.

\section{MeThodology}

Descriptive research design of a survey type was adopted for the study. The population consisted of all Business and Accounting Education students in University of Nigeria, Nsukka, Ikere-Ekiti Campus totaling 500. The sample consisted of 80 students randomly selected from all the four levels of each department. Ten students each were selected from each level, totaling $80 \mathrm{in}$ all. The instrument was a questionnaire, rated on a four-point adapted Likert scale of Strongly Agree $(\mathrm{SA})=4$; Agree $(\mathrm{A})=3$; Disagree $(\mathrm{D})=2$ and Strongly Disagree $(\mathrm{SD})=1$. The questionnaire contained 19 items to ascertain the level of preparedness and entrepreneurship consciousness of business education/accounting students in facing unemployment challenges. The validity was ensured through experts in accounting and business education departments. The crombach alpha method of reliability was employed and a coefficient of 0.72 was obtained. Data collected were analyzed using descriptive statistics of percentage, means and standard deviation to answer the research questions while inferential statistics of t-test was used to test the hypotheses at 0.05 level of significance. 
Restructuring the Business/Accounting Education Curriculum for Sustainable Development: Instilling Entrepreneurial Consciousness into Students in Tertiary Institutions

\section{Results}

Research Question 1: Are business/accounting education students aware of the unemployment situation in the country and are they prepared to face the challenges?

Table1. Students' level of awareness of the unemployment situation in the country and their preparedness to face the challenges

\begin{tabular}{|c|c|c|c|c|c|c|c|c|}
\hline $\mathrm{S} / \mathrm{N}$ & ITEM & SA & $\mathrm{A}$ & $\mathrm{D}$ & SD & Mean & S.D & Remark \\
\hline 1 & $\begin{array}{l}\text { I am aware of the fact that there is } \\
\text { no employment out there in the } \\
\text { world of work. }\end{array}$ & $\begin{array}{l}30 \\
(37.5 \%)\end{array}$ & $\begin{array}{l}34 \\
(42.5 \%)\end{array}$ & $8(10 \%)$ & $\begin{array}{l}8 \\
(10 \%)\end{array}$ & 3.07 & 0.93 & Agreed \\
\hline 2 & $\begin{array}{l}\text { I am well equipped to face the } \\
\text { unemployment challenges in the } \\
\text { society. }\end{array}$ & $\begin{array}{l}26 \\
(32.5 \%)\end{array}$ & $\begin{array}{l}39 \\
(48.8 \%)\end{array}$ & $\begin{array}{l}10 \\
(12.5 \%)\end{array}$ & $\begin{array}{l}5 \\
(6.3 \%)\end{array}$ & 3.08 & 0.83 & Agreed \\
\hline 3 & $\begin{array}{l}\text { With my entrepreneur knowledge, } \\
\text { I could handle my own business } \\
\text { after school. }\end{array}$ & $\begin{array}{l}45 \\
(56.3 \%)\end{array}$ & $\begin{array}{l}28 \\
(35 \%)\end{array}$ & $\begin{array}{l}5 \\
(6.3 \%)\end{array}$ & $\begin{array}{l}2 \\
(2.5 \%)\end{array}$ & 3.45 & 0.72 & Agreed \\
\hline 4 & $\begin{array}{l}\text { I possess entrepreneurial skills } \\
\text { that are saleable }\end{array}$ & $\begin{array}{l}30 \\
(37.5 \%)\end{array}$ & $\begin{array}{l}41 \\
(51.3 \%)\end{array}$ & $\begin{array}{l}9 \\
(11.3 \%)\end{array}$ & - & 3.26 & 0.65 & Agreed \\
\hline 5 & $\begin{array}{l}\text { I possess skills that can earn me a } \\
\text { useful living within the society. }\end{array}$ & $\begin{array}{l}38 \\
(47.5 \%) \\
\end{array}$ & $\begin{array}{ll}36 \\
(45 \%) \\
\end{array}$ & $\begin{array}{l}5 \\
(6.3 \%) \\
\end{array}$ & $\begin{array}{l}1 \\
(1.3 \%) \\
\end{array}$ & 3.38 & 0.66 & Agreed \\
\hline 6 & $\begin{array}{l}\text { I prefer to be an employer of } \\
\text { labour. }\end{array}$ & $\begin{array}{l}26 \\
(32.5 \%)\end{array}$ & $\begin{array}{l}35 \\
(43.8 \%)\end{array}$ & $\begin{array}{l}16 \\
(20 \%)\end{array}$ & $\begin{array}{l}3 \\
(3.8 \%) \\
\end{array}$ & 3.05 & 0.82 & Agreed \\
\hline 7 & $\begin{array}{l}\text { I possess skills necessary for the } \\
\text { improvement of the nation's } \\
\text { economy. }\end{array}$ & $\begin{array}{l}33 \\
(41.3 \%)\end{array}$ & $\begin{array}{l}37 \\
(46.3 \%)\end{array}$ & $8(10 \%)$ & $\begin{array}{l}2 \\
(2.5 \%)\end{array}$ & 3.26 & 0.74 & Agreed \\
\hline 8 & $\begin{array}{l}\text { I possess physical and intellectual } \\
\text { skills which could enable me to } \\
\text { be self-employed and to be a } \\
\text { useful member of the society. }\end{array}$ & $\begin{array}{l}37 \\
(46.3 \%)\end{array}$ & $\begin{array}{l}39 \\
(48.8 \%)\end{array}$ & $\begin{array}{l}3 \\
(3.8 \%)\end{array}$ & $\begin{array}{l}1 \\
(1.3 \%)\end{array}$ & 3.40 & 0.63 & Agreed \\
\hline 9 & $\begin{array}{l}\text { I can start and manage a business } \\
\text { successfully. }\end{array}$ & $\begin{array}{l}37 \\
(46.3 \%)\end{array}$ & $\begin{array}{l}38 \\
(47.5 \%) \\
\end{array}$ & $\begin{array}{l}5 \\
(6.3 \%) \\
\end{array}$ & - & 3.40 & 0.61 & Agreed \\
\hline 10 & $\begin{array}{l}\text { I will not wait to see who will } \\
\text { give me job, but rather seize the } \\
\text { opportunity to secure my future. }\end{array}$ & $\begin{array}{l}42 \\
(52.5 \%)\end{array}$ & $\begin{array}{l}33 \\
(41.3 \%)\end{array}$ & $\begin{array}{l}5 \\
(6.3 \%)\end{array}$ & - & 3.46 & 0.62 & Agreed \\
\hline 11 & $\begin{array}{l}\text { I can create job and livelihood for } \\
\text { others through my entrepreneurial } \\
\text { skills. }\end{array}$ & $\begin{array}{l}28 \\
(35 \%)\end{array}$ & $\begin{array}{l}43 \\
(53.8 \%)\end{array}$ & $\begin{array}{l}9 \\
(11.3 \%)\end{array}$ & - & 3.23 & 0.64 & Agreed \\
\hline & \multicolumn{5}{|l|}{ Grand mean } & 3.27 & 0.45 & Agreed \\
\hline
\end{tabular}

\subsection{Mean greater than 2.50 "agree" otherwise "disagree"}

The results presented in Table 1 above as regards students' awareness of the unemployment situation in the country and their preparedness to face the challenges revealed that all the respondents indicated that they are aware of the fact that there is no employment out there in the world of work and that they are prepared to face the unemployment challenges. This implies that students have high level of awareness of the unemployment situation in Nigeria and they are highly prepared to face the challenges. The grand mean value of respondents in the table was greater than 2.50. This further confirms that students are aware of the unemployment situation in Nigeria and they are prepared to face the challenges.

Research Question 2: Are business/accounting education students aware of the unemployment situation in the country and do they have the entrepreneurship consciousness for self- sustainability?

Table2. Students' awareness of the unemployment situation in Nigeria and their entrepreneurship consciousness for self-sustainability

\begin{tabular}{|l|l|l|l|l|l|l|l|l|}
\hline S/N & Item & SA & A & D & SD & Mean & S.D & Remark \\
\hline 1 & $\begin{array}{l}\text { I am feeling conscious of } \\
\text { what to do after my } \\
\text { studies. }\end{array}$ & $\begin{array}{l}22 \\
(27.5 \%)\end{array}$ & $\begin{array}{l}34 \\
(42.5 \%)\end{array}$ & $16(20 \%)$ & $8(10 \%)$ & 2.87 & 0.93 & Agreed \\
\hline 2 & $\begin{array}{l}\text { I prefer to take up } \\
\text { employment with the } \\
\text { government. }\end{array}$ & $\begin{array}{l}11 \\
(13.8 \%)\end{array}$ & $\begin{array}{l}30 \\
(37.5 \%)\end{array}$ & $\begin{array}{l}29 \\
(36.3 \%)\end{array}$ & $\begin{array}{l}10 \\
(12.5 \%)\end{array}$ & 2.52 & 0.88 & Agreed \\
\hline
\end{tabular}


Restructuring the Business/Accounting Education Curriculum for Sustainable Development: Instilling Entrepreneurial Consciousness into Students in Tertiary Institutions

\begin{tabular}{|c|c|c|c|c|c|c|c|c|}
\hline 3 & $\begin{array}{l}\text { I prefer to take up } \\
\text { employment with the } \\
\text { private sector. }\end{array}$ & $\begin{array}{l}13 \\
(16.3 \%)\end{array}$ & $\begin{array}{l}27 \\
(33.8 \%)\end{array}$ & $28(35 \%)$ & $\begin{array}{l}12 \\
(15 \%)\end{array}$ & 2.51 & 0.94 & Agreed \\
\hline 4 & $\begin{array}{l}\text { I don't have the ability to } \\
\text { set up a business of my } \\
\text { own. }\end{array}$ & $\begin{array}{l}7 \\
(8.8 \%)\end{array}$ & $\begin{array}{l}12 \\
(15 \%)\end{array}$ & $\begin{array}{l}35 \\
(43.8 \%)\end{array}$ & $\begin{array}{l}26 \\
(32.5 \%)\end{array}$ & 2.00 & 0.91 & Disagreed \\
\hline 5 & $\begin{array}{l}\text { I will need extra training } \\
\text { before i can set up my own } \\
\text { business. }\end{array}$ & $\begin{array}{l}13 \\
(16 \%)\end{array}$ & $\begin{array}{l}29 \\
(36.3 \%)\end{array}$ & $\begin{array}{l}29 \\
(36.3 \%)\end{array}$ & $\begin{array}{l}9 \\
(11.3 \%)\end{array}$ & 2.57 & 0.89 & Agreed \\
\hline 6 & $\begin{array}{l}\text { I cannot take the risk } \\
\text { associated with operating } \\
\text { business. }\end{array}$ & $\begin{array}{l}12 \\
(15 \%)\end{array}$ & $\begin{array}{l}20 \\
(25 \%)\end{array}$ & $\begin{array}{l}23 \\
(28.8 \%)\end{array}$ & $\begin{array}{l}25 \\
(31.3 \%)\end{array}$ & 2.23 & 1.05 & Disagreed \\
\hline 7 & $\begin{array}{l}\text { The entrepreneur } \\
\text { training/course I passed } \\
\text { through in school will help } \\
\text { me. }\end{array}$ & $\begin{array}{l}27 \\
(33.8 \%)\end{array}$ & $\begin{array}{l}40 \\
(50 \%)\end{array}$ & $\begin{array}{l}9 \\
(11.3 \%)\end{array}$ & $4(5 \%)$ & 3.12 & 0.80 & Agreed \\
\hline 8 & $\begin{array}{l}\text { My exposure during } \\
\text { SIWES orientates me of } \\
\text { what is happening in the } \\
\text { world of work. }\end{array}$ & $\begin{array}{l}30 \\
(37.5 \%)\end{array}$ & $\begin{array}{l}38 \\
(47.5 \%)\end{array}$ & $3(3.8 \%)$ & $\begin{array}{l}9 \\
(11.3 \%)\end{array}$ & 3.11 & 0.92 & Agreed \\
\hline & \multicolumn{5}{|l|}{ Grand mean } & 2.61 & 0.91 & Agreed \\
\hline
\end{tabular}

\subsection{Mean Greater Than 2.50 "Agreed" Otherwise "Disagreed"}

The results presented in Table 2 above as regards students' awareness of the unemployment situation in the country and their entrepreneurship consciousness for self-sustainability reveal that although they are aware of unemployment challenges, think they are prepared, but have not consciousness at all for self-sustenance at the end of the school. This is because out of the eight items in the table, respondents agree with six. This implies that students are aware of the unemployment situation in the country but they do not have the entrepreneurship consciousness for self-sustainability. The grand mean value is greater than 2.50. This further confirms that both male and female students are aware of the unemployment situation in the country but have very low entrepreneurship consciousness for selfsustainability.

\subsection{Test of Hypothesis}

Hypothesis 1: There is no significance difference in the responses of Business and Accounting Education students on awareness of the unemployment situation in Nigeria and their preparedness to face the challenges.

Table3. $t$-test analysis of Business/Accounting students' level of awareness of the unemployment situation in Nigeria and their preparedness to face the challenges

\begin{tabular}{|l|l|l|l|l|l|l|l|}
\hline Students & N & Mean & Std. Dev & Df & T. Cal. & T. Table & Inference \\
\hline Business Students & 40 & 3.300 & 0.757 & & & & \\
\cline { 1 - 4 } Accounting Students & 40 & 3.275 & 0.750 & 78 & 0.154 & 1.960 & Not Significant \\
\hline
\end{tabular}

P $>0.05$ (Significant)

The results of analysis presented in Table 3 reveal that there is no significant difference in the responses of Business/Accounting Education students on awareness of the unemployment situation in Nigeria and their preparedness to face the challenges as $t_{\text {cal }}(0.154)$ is less than $t_{\text {tab }}(1.960)$ at 0.05 level of significance. This makes null hypothesis one to be upheld. This means that both Business/Accounting Education students are aware of the unemployment situation in Nigeria and they are prepared to face the challenge.

Hypothesis 2: There is no significant difference in the responses of Business and Accounting Education students on awareness of the unemployment situation in Nigeria and their entrepreneurship consciousness for self-sustainability. 
Restructuring the Business/Accounting Education Curriculum for Sustainable Development: Instilling Entrepreneurial Consciousness into Students in Tertiary Institutions

Table4. $t$-test analysis of Business/Accounting students' level of awareness of the unemployment situation in Nigeria and their entrepreneurship consciousness for self-sustainability

\begin{tabular}{|l|l|l|l|l|l|l|l|}
\hline Students & N & Mean & Std. Dev & Df & T. & T. Table & Inference \\
\hline Business Students & 40 & 2.950 & 0.845 & \multirow{2}{*}{78} & \multirow{2}{*}{0.845} & \multirow{2}{*}{1.960} & \multirow{2}{*}{ Not Significant } \\
\hline Accounting Students & 40 & 2.800 & 1.017 & 78 & \\
\hline
\end{tabular}

$\mathrm{P}>0.05$ (Significant)

The results of analysis presented in Table 4 reveals that there is no significant difference in the level of awareness and preparedness of Business/Accounting Education students of unemployment situation in Nigeria and their entrepreneurship consciousness for self-sustainability as $t_{\text {cal }}(0.845)$ is less than $t_{\text {tab }}$ (1.960) at 0.05 level of significance. This makes null hypothesis two to be upheld. This means that both Business/Accounting students are aware of the unemployment situation in Nigeria but have low level of entrepreneurship consciousness for self-sustainability.

\section{DISCUSSION}

Results in Table 1 reveal that Business/Accounting Education students are quite aware that there is unemployment challenge out there in the world of work and think they are well prepared to face the challenges. However, their thinking is just a wishful thinking as revealed in table 2 because most of them do not have consciousness to create jobs and be self-dependent when they pass out of school. Majority of them have not learnt any trade as at now and some of them are not prepared to learn, yet they said they are prepared. This will not help to achieve the purpose of entrepreneurship education. One major reason for this is because the entrepreneurship education is still theoretically based. There is the need to practice entrepreneurship education by setting up entrepreneurship centres when students can get practical experiences.

This is in line with Okoro's (2013) view that in business education, curriculum thrives on relevance and usefulness. The extent to which a curriculum assists students to enter and succeed in the business world-of-work is what matters most. Also, the findings reveal that there is need for concrete knowledge as Udu (2014) observed that universities should encourage multidisciplinary entrepreneurship clubs formation through the gathering and networking of students with related felt need and world view by providing incubation centers of medium standard for the students and staff to test the feasibility and viability of any germane idea generated either in the clubs or through networks under the guidance of experts.

\section{CONCLUSION}

The study looks into the need to inculcate entrepreneurship consciousness into business/accounting education students in tertiary institutions. Although these are skill based courses that can help students to be self-dependent and job creators after graduation, instilling entrepreneurship consciousness into entrepreneurship education by way of providing practical experiences, will, by no small means, increase self-sustainability of business/accounting education graduates and reduce unemployment in the country and thereby reducing many social vices that are currently ravaging the nation.

\section{RECOMMENDATIONS}

Based on the findings, it was recommended that:

* The curriculum should be restructured to ensure that entrepreneurship is emphasized in core areas in business/accounting education.

* Tertiary institutions should provide entrepreneurship centres where students can have practical experiences that will quicken the consciousness in them.

* Students should be graded at least $80 \%$ practical in entrepreneurship courses to instill the consciousness into them.

* Students should be educated on the benefits and the potential they have if they engage in entrepreneurial activities.

* Entrepreneurship culture should be cultivated among undergraduates in order to make them ready for the world of work. 
Restructuring the Business/Accounting Education Curriculum for Sustainable Development: Instilling Entrepreneurial Consciousness into Students in Tertiary Institutions

* Entrepreneurs should be invited to schools to give seminar/workshop talks and share experiences with students.

It is believed that all the above recommendations will help to instill the entrepreneurship consciousness into students and prepare them for the world of work and to combat the unemployment challenges they may face when they graduate.

\section{REFERENCES}

[1] Ahmad, S. Z. (2013). The need for inclusion of entrepreneurship education in Malaysia lower and higher learning institutions. Education + Training, 55(2), 191-203. http://dx.doi.org/10.1108/004009113 11304823

[2] Akhuemonkhan, I. A., Raimi, L., \& Sofoluwe, A. O. (2013). Entrepreneurship education and employment stimulation in Nigeria. Journal of Studies in Social Sciences, 3, 55-79. Retrieved from http://infinitypress.info/index.php/jsss/article/viewFile/66/77

[3] Akudolu, L. (2010). A curriculum framework for entrepreneruship education in Nigeria. Unizik Orient Journal of Education, 1-16. Retrieved from http://scholar.google.com.my/scholar?q=A+Curriculum+ Framework+for+Entrepreneruship+Education+in+Nigeria\&btnG $=\& \mathrm{hl}=$ en \&as_sdt=0\%2C5

[4] Alain, F. (2009). Entrepreneurship education in Europe: Trends and ehallenges. OECD LEED programme: Universities, Innovations and entrepreneruship good practice workshop. Retrieved from http://www.oecd. org/regional/leed/43202553.pdf

[5] Aliyu, M.M (2006). Business Education in Nigeria: Trends and issues. Ilorin. Goshy Multimedia.

[6] Aniekwu, N. \& Ozochi, C. A. (2010): Restructuring education, training and human-resource development in the Nigerian Construction Industry. Journal of Science and Technology Education Research. 1(5), 92 98, October. http://www.acad emicjournals.org/JSTER.

[7] Ayara, N. N. (2007). "A dynamic analysis of education and economic growth in Nigeria". Journal of Developing Areas. The Fall.

[8] Bakar, R.; Islam, A. \& Lee, J. (2015): Entrepreneurship Education: Experiences in selected countries. International Education Studies; 8(1); 88 - 99. ISSN 1913-9020 E-ISSN 1913-9039 Published by Canadian Center of Science and Education.

[9] Elumelu. T. (2015): Entrepreneurship programme. A paper presented during the postgraduate graduation ceremony of Babcock University in Ilisan Remo, Ogun state on June 4.

[10] Enu.D.2012. Enhancing the entrepreneurship education in Nigeria. American Journal of Social Issues and Humanities. 2(4), 232-239. Retrieved from http//:www.ajsih.org/index.php /ajsih/article/view/54/54.

[11] Esene, R.A. (2012). Methods of teaching vocational business subjects. Royal Pace Publications.

[12] Gabadeen, W. O., \& Raimi, L. (2012). Management of entrepreneurship education in Nigerian higher institutions: Issues, challenges and way forward. Abuja International Journal of Education And Management Sciences, 1-26. Retrieved from http://scholar.google.com. my/ scholar?q=related:K WVtF42gIwQJ: scholar.google.com/\&hl=en\&as_sdt=0,5

[13] Ifedili, C. \& Ofoegbu, F. (2011). Managing entrepreneurship education in Nigerian universities. European Journal of Educational Studies. Retrieved from http://memberfiles.freewebs.com/56/91/558 39156/documents/MANAGING\%20ENTREPRENEURSHIP\%20EDUCATION\%20IN\%20NIGERIAN \%20UNIVERSITIES.pdf

[14] Imam, H. (2001). The cultural practice of Almajirci education and its Socio-Political implication. Journal of Development and Society, 1(3), 46-53.

[15] Isineyi, T. N. (2008). Redefinition of the goal and objectives of business education programmes to make the graduate meet the expectations of Employers. Association of Business Educators of Nigeria. Book of Readings.1 (8), 216-223.

[16] Isyaku, S. (2006). Business education for self-reliance. Issues and relevance. Association of Business Educators of Nigeria. Book of Readings. 1(3), 97-104.

[17] Kuratko, D. (2003). Entrepreneurship education: Emerging trends and challenges for the 21st century. Coleman White Paper Series. Retrieved from http://www.unm.edu/ asalazar/ Kauffman/Entrep_research le_ed.pdf

[18] Matlay, H. (2008). The impact of entrepreneurship education on entrepreneurial outcomes. Journal of Small Business and Enterprise Development, 15, 382-396. http://dx.doi.org/10.1108/1462600 0810871745

[19] Nwite, O. (2016): Entrepreneurship education in Nigerian tertiary institutions: A remedy to graduates unemployment. British Journal of Education, 4(5), 16-28, May. Published by European Centre for Research Training and Development UK (www.eajournals.org) 
Restructuring the Business/Accounting Education Curriculum for Sustainable Development: Instilling Entrepreneurial Consciousness into Students in Tertiary Institutions

[20] Ogakwu, V.N. (2011). "Refocusing education in Nigeria in the $21^{\text {st }}$ century" in P. Egbule, J.E. Tabotndip and D.A. Aboho (2011). Lagos: West and Solomon Publishing Coy Ltd. 20 -26.

[21] Oghiagbephan, A.D. (2015): Restructuring educational goals for national and economic development in Nigeria. IOSR Journal of Research \& Method in Education (IOSR-JRME). e-ISSN: 2320-7388,p-ISSN: 2320-737X. 5(4), 08 -14. Ver. II (Jul - Aug.). www.iosrjournals.org DOI: 10.9790/7388-05420814

[22] Okike, O.N. (2011). Restructuring business education curriculum for entrepreneurship development at tertiary instruction level. Association of Business Educators of Nigeria. Book of Readings. 1(11). 204-208.

[23] Okoli, B. E. \& Azih, N. (2015): Re-Engineering the Business education programme in universities for enhanced human resources development in Nigeria. Journal of Education and Practice www.iiste.org ISSN 2222-288X. 6 (17), $93-96$.

[24] Okoro, J. (2013): Ideal quality of university Business education curriculum required for successful graduates employment as perceived by lecturers. Journal of Education and Practice www.iiste.org ISSN 2222-1735 (Paper) ISSN 2222-288X (Online) 4 (15), 114 - 118.

[25] Peter, L. (2015): An analysis of the relevance of curriculum content of entrepreneurship development in higher educational system in Nigeria. Paper Presented at the 3rd School of Education and Humanities International Conference on the Future of Higher Education in Africa held at Babcock University. August 24-26.

[26] Rahim, E. (2014): 10 Ways universities can improve entrepreneurship education. https://mobile.twitter. com/DrEmadRahim

[27] Udu, A. A. (2014): Handling entrepreneurship in tertiary institutions in Nigeria. Journal of Management and Sustainability; 4(1); 189 - 193. ISSN 1925-4725 E-ISSN 1925-4733. Published by Canadian Center of Science and Education.

[28] Uwadiegwu, I. O. (2013): The challenging issues in restructuring Nigeria Certificate in Education (N.C.E) Vocational and Technical Education Programmes. Journal of Resourcefulness and Distinction. 6 (1), 1 - 8. December.

Citation: Dr. Fasae, Felicia Bosede Kehinde, Dr. Adeosun, Omoniyi Alabi. "Restructuring the Business/Accounting Education Curriculum for Sustainable Development: Instilling Entrepreneurial Consciousness into Students in Tertiary Institutions" International Journal of Humanities Social Sciences and Education (IJHSSE), vol 8, no. 9, 2021, pp. 1-10. doi: https://doi.org/10.20431/2349-0381.0809001.

Copyright: () 2021 Authors. This is an open-access article distributed under the terms of the Creative Commons Attribution License, which permits unrestricted use, distribution, and reproduction in any medium, provided the original author and source are credited. 